\title{
PERBANDINGAN TEOLOGI KESELAMATAN ANTARA KATOLIK DAN PROTESTAN SEBELUM DAN SESUDAH GERAKAN REFORMASI
}

\author{
Marde Christian Stenly Mawikere \\ PESAT Wilayah Papua \\ Jl. SD. Percobaan 39, Wamena, Kabupaten Jayawijaya, Papua \\ Email: mardestenly@gmail.com
}

\begin{abstract}
Marde Christian Stenly Mawikere, Salvation theological comparison between Catholic and protestant before and after reform. This article is an overview of comparative theology Safety between Catholics and Protestants Before and After Reform based review of the literature has been provided. Departing from the historical context of the socio-religious Europe since the 5th century to 1517 which shows the blend between philosophy and theology of the church led to deviate from the teachings of the Bible. The situation Christianity and medieval zeitgeist called dark ages of the church which fueled the Protestant reform movement. The Protestant reform movement seemed to be a renaissance of the church to return to the Bible, especially the problem of salvation (soteriology), emphasizing the supremacy of God's grace and Christ's Atonement.
\end{abstract}

Keyword: Theocentric, Reformed Theology, Soteriology

ABSTRAK: Marde Christian Stenly Mawikere, Perbandingan Teologi Keselamatan Antara Katolik Dan Protestan Sebelum Dan Sesudah Gerakan Reformasi. Artikel ini merupakan tinjauan perbandingan Teologi Keselamatan Antara Katolik dan Protestan Sebelum dan Sesudah Reformasi berdasarkan ulasan literatur yang telah tersedia. Berangkat dari konteks historis socio religious di Eropa sejak abad 5 sampai 1517 yang menunjukkan paduan antara filsafat dengan teologi menyebabkan gereja menyimpang dari ajaran Alkitab. Situasi kekristenan dan zeit geist abad pertengahan yang disebut abad kegelapan gereja memicu lahirnya gerakan reformasi protestan. Gerakan reformasi protestan seakan menjadi renaissance gereja untuk kembali kepada pemahaman Alkitab, terutama masalah keselamatan (soteriologi) yang menekankan supremasi anugerah Allah dan Penebusan Kristus.

Kata Kunci: Theosentris, Teologi Reformasi, Soteriologi.

\section{PENDAHULUAN}

Sejak abad ke 5 sampai pada tahun 1517 , benua Eropa adalah sebuah benua Roma Katolik yang dipimpin oleh para Paus. Pada tahun 1517 Paus Leo $\mathrm{X}$ membutuhkan biaya yang sangat besar untuk menyelesaikan pembangunan gedung Gereja Santo Petrus yang megah di Roma, maka dikeluarkannya pengajaran mengenai surat penghapusan siksa atau indulgen yang dapat dibayar oleh setiap orang berdosa yang membutuhkan keselamatan. Bahkan Paus Sixtus IV, mengajarkan bahwa manfaat dari indulgen tersebut dapat dikenakan kepada orang-orang Kristen yang berada di api penyucian (purtagorium) yang dapat membawa mereka kepada kehidupan kekal. Di negara Jerman ada seorang uskup wilayah bernama Johannes Tetzel yang mengajarkan bahwa pada saat uang koin berdenting di dalam peti, maka jiwa meloncat keluar dari api penyucian. ${ }^{1}$ Itulah yang menjadi Injil versi Roma Katolik pada masa itu dan secara luas merupakan kondisi kekristenan pada masa itu yang mana Paus yang memiliki dan menentukan keselamatan manusia dan dalam upaya untuk memperoleh keselamatan itu manusia harus beramal atau berbuat baik sehingga tidak mengandalkan kasih karunia Allah. Ajaran semacam ini merupakan warisan dari ajaran Pelagius, seorang teolog Inggris yang meninggal tahun 419 yang mengajarkan bahwa perbuatan manusialah yang menentukan keselamatannya. ${ }^{2}$ Adapun dalam gereja Roma Katolik sebelum terjadinya gerakan reformasi telah dipengaruhi

\footnotetext{
${ }^{1}$ Sinclair Ferguson, Anugerah Pertobatan (Bandung: Penerbit Mitra Pustaka, 2007), 12.

${ }^{2}$ Jan Sihar Aritonang, Garis Besar Sejarah Reformasi (Bandung: Jurnal Info Media, 2007), 6.
} 
oleh ajaran Pelagius maupun semi Pelagius berkaitan dengan ajaran mengenai keselamatan manusia. Selama periode Skolastik pada abad pertengahan memang perhatian yang lebih besar telah diberikan kepada teologi Augustinus, namun pelagianisme maupun semi pelagianisme telah mendapat tempat dalam gereja Roma Katolik secara menyeluruh. Erasmus, seorang tokoh gereja yang pada masa akhir hidupnya memiliki pandangan yang sama dengan Pelagius, yakni bahwa manusia dapat mencapai keselamatan dengan upaya-upaya mereka sendiri, tanpa anugerah Allah. ${ }^{3}$

Dalam situasi pengajaran mengenai teologi keselamatan yang telah menyimpang dari Alkitab itulah yang kemudian menjadi salah satu alasan bangkitnya reformasi gereja yang dipelopori oleh Martin Luther (1483-1546) dengan menempelkan 95 tesis pada pintu gedung gereja di Universitas Wittenberg, Jerman pada tanggal 31 Oktober $1517^{4}$. Oleh pemahaman Luther akan Alkitab, ia meyakini bahwa Injil tidak meminta sebuah tindakan mengaku dosa kepada rohaniwan, melainkan sebuah perubahan pemikiran mendasar yang akan memimpin kepada transformasi hidup secara mendalam. Menurut Luther, pertobatan adalah karakteristik seluruh kehidupan, bukan sebuah tindakan sesaat. Keselamatan adalah anugerah yang diterima hanya didalam Kristus (sola Christo), hanya melalui anugerah (sola gracia), hanya di dalam iman (sola fide). Namun itulah keselamatan, dan keselamatan berarti orang percaya benar-benar diselamatkan. Jika tidak, berarti tidak dapat mengenal Kristus sebagai Sang Juruselamat ${ }^{5}$. Sejak saat itu, maka dimulailah reformasi gereja yang dicetuskan oleh Martin Luther di Jerman dan kemudian diteruskan oleh Ulrich Zwingli (14841531) dan Heinrich Bullinger (1504-1575) di Swiss serta Johannes Calvin (1509-1564) yang mulai di

\footnotetext{
${ }^{3}$ Bernhard Lohse, Pengantar Sejarah Dogma Kristen (Jakarta: PT BPK Gunung Mulia, 2011), 167.

${ }^{4}$ Tony Lane, Runtut Pijar: Sejarah Pemikiran Kristiani (Jakarta: PT BPK Gunung Mulia, 2012), 132133.

${ }^{5}$ Ferguson, Anugerah Pertobatan, 13-14.
}

Prancis dan diteruskan di Swiss. Gerakan reformasi gereja adalah sebuah gerakan besar dalam kekristenan yang bukan saja menjadi awal kehadiran gerejagereja Protestan yang terpaksa memisahkan diri dari gereja Katolik namun menjadi titik balik upaya para Reformator untuk mengembalikan doktrin-doktrin utama kekristenan untuk kembali kepada Alkitab, ${ }^{6}$ terutama doktrin mengenai keselamatan (soteriologi) yang sangat penting dalam kekristenan.

Makalah ini membahas mengenai perbandingan teologi keselamatan antara Katolik dan Protestan sebelum dan sesudah gerakan reformasi dengan menyoroti mengenai aspek-aspek (doktrin) yang berkaitan dengan teologi keselamatan (soteriologi). Tidak semua aspek-aspek keselamatan dalam soteriologi akan dibahas, namun hanya akan membahas mengenai perbandingan yang mencolok antara pengajaran Katolik dan Protestan. Makalah ini dibangun berdasarkan studi literatur yang membahas mengenai soteriologi, khususnya yang memperbandingkan antara pemahaman Katolik dan Protestan.

\section{METODE}

Jenis penelitian yang digunakan dalam makalah ini adalah penelitian kualitatif. Sumber data dalam penelitian ini adalah buku-buku yang membahas teologi, sejarah pemikiran kristiani dan sejarah reformasi. Data yang diperoleh dari buku-buku tersebut dianalisis agar dapat membahas perbandingan dari perbandingan teologi keselamatan antara Katolik dan Protestan sebelum dan sesudah gerakan reformasi.

\section{PERBANDINGAN SOTERIOLOGI}

\section{Anugerah}

Perbedaan yang sangat mendasar antara teologi Roma Katolik dan teologi Protestan mengenai keselamatan adalah aspek anugerah atau kasih

\footnotetext{
${ }^{6}$ Alister E. McGrath, Sejarah Pemikiran Reformasi (Jakarta: BPK Gunung Mulia, 2012), 174-201.
} 
karunia. Seperti yang telah diungkapkan di atas, teologi keselamatan Roma Katolik berasal dari pelagianisme yang menekankan perbuatan baik manusia yang menentukan keselamatannya, bukan berdasarkan anugerah Allah. Menurut pengajaran Roma Katolik, perbuatan baik terdiri dari tiga cara yang berbeda. Pertama, perbuatan baik yang terhormat, perbuatan tersebut begitu terhormat sehingga harus diberi upah. Kedua, perbuatan baik yang serasi atau pantas, meskipun ini bukan perbuatan baik yang terhormat, perbuatan baik yang serasi atau pantas tersebut akan mendapatkan penghargaan dari Allah. Perbuatan baik yang serasi ini dicapai oleh manusia dengan melakukan sakramen pertobatan. Ketiga, perbuatan baik yang luar biasa, yaitu perbuatan baik yang melampaui apa yang dituntu. Perbuatan baik ini merupakan hal yang dicapai oleh orang-orang kudus. Perbuatan baik ini ditabung ke dalam tabungan perbuatan baik yang mana gereja dapat mengambilnya bagi orang-orang yang kekurangan perbuatan baik untuk dapat melewati api penyucian (purtagori) menuju surga. ${ }^{7}$

Gerakan Reformasi Protestan menyangkal teologi Roma Katolik yang menekankan pada usaha manusia untuk memperoleh anugerah atau penghargaan Allah secara transaksional tersebut. Teologi Protestan menyangkal dan memprotes ketiga pengajaran mengenai perbuatan baik dari Roma Katolik serta menegaskan bahwa perbuatan baik yang kita miliki adalah perbuatan baik dari Kristus. Karya Kristus datang kepada kita melalui anugerah atau kasih karunia berdasarkan iman. Anugerah merupakan belas kasihan Allah yang diberikan bukan berdasarkan perbuatan baik manusia melainkan merupakan tindakan atau inisiatif Allah terhadap kita manusia yang berdosa. Anugerah berdasarkan kemurahan pertolongan Roh Kudus yang tidak bergantung pada keberadaan manusia namun semata-mata hanya bersandar pada kemurahan Allah $^{8}$.

${ }^{7}$ R.C. Sproul, Kebenaran-Kebenaran Dasar Iman Kristen (Malang: Literatur SAAT, 2005), 263. ${ }^{8}$ Ibid, 264
Dengan demikian berkaitan dengan aspek anugerah, teologi Roma Katolik mengikuti pendapat Pelagianisme yang mengajarkan bahwa manusia dapat memperoleh keselamatan berdasarkan kekuatan sendiri atau "sinergistis" yaitu usaha bersama di antara kehendak bebas manusia dan rahmat Allah. Menurut Pelagius anugerah merupakan kemampuan diri manusia yang dimungkinkan melalui kemampuan manusia sendiri untuk tidak berdosa dan dalam bantuan yang diberikan Allah kepada manusia dari hukum dan perintah-Nya dalam pengampunan dosa yang dilakukan sebelum seseorang datang kepada Tuhan. Pada akhirnya manusia bisa saja tidak berdosa dan melakukan hukum Allah dengan mudah kalau manusia itu mau. Bagi Pelagianisme, anugerah tidak diperlukan untuk masuk ke surga atau untuk mencapai sebuah kehidupan tanpa dosa, melainkan anugerah memudahkan pencapaian kebenaran namun kebenaran dapat dicapai tanpa anugerah. ${ }^{9}$ Sedangkan teologi Reformasi Protestan mengikuti pendapat Augustinus (354-430) yang mengajarkan bahwa anugerah tidak tergantung pada syarat tertentu, melainkan harus dianggap sebagai pemberian belaka dari Allah. Para reformator maupun Augustinus menekankan anugerah sebagai kebaikan kehendak Allah yang ditunjukkan kepada orang berdosa, yang memberikannya dengan cara yang menyingkirkan semua jasa dari pihak orang berdosa. ${ }^{10}$ Bahkan mengikuti pendapat Augustinus pula, para reformator memahami anugerah mempengaruhi seseorang sebelum ia sendiri berkehendak, mendorong kehendaknya. Ia mengikuti akta berkehendak, kalau tidak demikian maka seseorang akan frustrasi. ${ }^{11}$ Ajaran anugerah ini bersifat "monergistis", yaitu keselamatan manusia hanya diperoleh melalui anugerah saja. Anugerah merupakan kekuatan yang mengubahkan yang mana mereka yang dipilih ditarik ke luar dari

${ }^{9}$ R.C. Sproul, Hanya Melalui Iman (Bandung: Penerbit Mitra Pustaka, 2004), 185-186.

${ }^{10}$ Louis Berkhof, Teologi Sistematika, Jilid 4 (Surabaya: Momentum, 2001), 35-36.

${ }^{11}$ Lohse, Pengantar Sejarah, 146. 
orang-orang yang terkutuk dan menerima keselama$\tan ^{12}$

\section{Predestinasi}

Ajaran mengenai predestinasi erat kaitannya dengan ajaran mengenai anugerah. Teologi Roma Katolik pada abad pertengahan lebih cenderung kepada pelagianisme yang menekankan tentang anugerah dan keselamatan yang dari Allah diimbangi dengan jasa dan kehendak bebas manusia. Ajaran Pelagius sangat menekankan kemampuan dan kehendak bebas manusia untuk berbuat baik maupun untuk menerima atau menolak anugerah dan keselamatan dari Allah. ${ }^{13}$ Sedangkan teologi reformasi menegaskan bahwa semua usaha manusia untuk menyelamatkan diri adalah sia-sia, karena dasar dari keselamatan manusia adalah predestinasi. Gerakan reformasi mengikuti pengajaran Augustinus mengenai predestinasi sebagai anugerah Allah yang memilih sejumlah orang (tidak semuanya) untuk diselamatkan. Predestinasi merupakan kasih karunia yang bekerja dengan mendahului setiap kemanuan berbuat baik dari pihak manusia. Martin Luther mendukung pengajaran Augustinus tersebut, sedangkan Johanes Calvin melanjutkan bahkan mensistematiskan doktrin predestinasi. Menurut Calvin, predestinasi berarti bahwa jumlah dan jati diri dari orang-orang yang terpilih yakni mereka yang diselamatkan, sudah ditetapkan oleh Allah yang berdaulat itu sebelum dunia diciptakan oleh Allah. Predestinasi merupakan keputusan Allah yang kekal, yang dengannya Ia menetapkan untuk diri-Nya sendiri, apa yang menurut kehendak-Nya akan terjadi atas setiap orang ${ }^{14}$.

Dengan demikian perbedaan yang terbesar antara teologi Roma Katolik dan Reformasi Protestan mengenai predestinasi adalah teologi Roma Katolik mengikuti pandangan Pelagius bahwa pemilihan Allah didasarkan pada pra pengetahuan Allah

\footnotetext{
${ }^{12}$ Dieter Becker, Pedoman Dogmatika (Jakarta: PT BPK Gunung Mulia, 2012), 140.

${ }^{13}$ Aritonang, Garis Besar Sejarah, 99.
${ }^{14}$ Ibid, 100.
}

akan keputusan tanggapan dan partisipasi yang diberikan oleh manusia dalam keselamatan. Sedangkan teologi reformasi menekankan bahwa keputusan keselamatan manusia yang terletak pada Allah saja. Pemilihan Allah adalah berdasarkan kedaulatanNya. Dia memiliki hak untuk bermurah hati kepada siapa Ia berkenan untuk bermurah hati tanpa pertimbangan akan partisipasi manusia. ${ }^{15}$

\section{Penebusan}

Berkaitan dengan doktrin penebusan, sebenarnya teologi Roma Katolik mengakui karya penebusan yang dilakukan oleh Yesus Kristus di kayu salib sebagai karya untuk membayar dengan harga tunai karena manusia telah berdosa. Hal ini karena gereja Roma Katolik dipengaruhi oleh teori-teori tentang penebusan yang diajarkan oleh para Bapa Gereja maupun teologi abad pertengahan. Origen (185254) mengajarkan mengenai penebusan sebagai pembayaran kepada setan. Dengan kejatuhan manusia dalam dosa maka setan telah menawan manusia sehingga biaya penebusan harus dibayar kepada setan dan bukan kepada Allah. Pandangan Origen ini juga dipegang oleh Augustinus. Irenaeus (130-200) mengajarkan tentang teori rekapitulasi, yaitu Yesus Kristus telah melalui fase kehidupan dan pengalaman manusia/Adam, termasuk pengalaman berdosa sekalipun Kristus tidak berdosa. Adam telah gagal, namun Kristus adalah Adam yang terakhir. Anselm (1033-1109) dengan teori komersialnya mengajarkan bahwa melalui dosa, kemuliaan yang seharusnya diberikan kepada Allah telah dirampas. Karena itu mengharuskan adanya resolusi yang dapat dicapai baik melalui Penghukuman orang berdosa maupun melalui pemuasan. Allah telah memilih dan memutuskan untuk menyelesaikan persoalan ini melalui pemuasan dengan pemberian Putra-Nya Yesus Kristus. Melalui kematian Tuhan Yesus Kristus, maka Ia membawa kemuliaan kepada Allah, dan menerima suatu upah, kemudian Dia meneruskannya pada

\footnotetext{
${ }^{15}$ Sproul, Kebenaran-Kebenaran, 216-217.
} 
orang berdosa. Hal inilah yang disebut sebagai anugerah, yaitu pengampunan bagi orang berdosa dan kehidupan kekal bagi mereka yang hidup menurut Injil. Pandangan Anselm ini menekankan anugerah Allah dan penderitaan Kristus dengan mengesampingkan keadilan dan kekudusan Allah sebagai atribut-Nya. ${ }^{16}$ Penekanan pandangan Anselm dengan teori komersial mengenai Kristus yang mati sebagai akibat dari dosa kemudian diambil oleh gereja Roma Katolik dalam konsep penebusan dosa, yaitu konsep "pelunasan yang diberikan sesuai dengan banyaknya pelanggaran"17.

Pandangan berikutnya adalah teori pengaruh moral dari Abelard (1079-1142) yang mengajarkan bahwa kematian Kristus tidak dibutuhkan sebagai penebusan untuk dosa, melainkan sebagai demonstrasi kasih Allah terhadap umat manusia sedemikian rupa sehingga hati orang berdosa menjadi tergerak dan memimpin kepada pertobatan. ${ }^{18}$ Dengan demikian, sekalipun teologi penebusan dalam Roma Katolik sangat dipengaruhi oleh pendapat-pendapat yang berbeda dari para teolog patriastik maupun abad pertengahan, namun mereka tetap mengakui realitas adanya karya Tuhan Yesus Kristus di salib sebagai karya penebusan. Akan tetapi doktrin tentang penebusan Tuhan Yesus Kristus ini menjadi semakin luas dengan adanya penambahan yang dilakukan oleh Roma Katolik berkaitan dengan adanya sakramen pengakuan dosa dan surat penghapusan dosa (indulgensia) yang mencampuradukan antara pengampunan dosa yang diperoleh karena jasa Kristus serta jasa khusus dari Maria dan orang-orang kudus, bahkan jasa seseorang yang menginginkan keselamatan. Menurut gereja Roma Katolik indulgensia adalah remis atau penghapusan hukuman di hadapan Allah atas hukuman sementara yang disebabkan oleh dosa-dosa yang telah diampuni. Indulgensia tersebut

\footnotetext{
${ }^{16}$ Jonar Situmorang, Soteriologi: Doktrin Keselamatan (Yogyakarta: Penerbit Andi, 2015), 192-193.

${ }^{17}$ Paul Enns, The Moody Handbook of Theology, Jilid 1 (Malang: Literatur SAAT, 2014), 362.

${ }^{18}$ Charles Ryrie, Teologi Dasar 2 (Yogyakarta: Andi, 2006), 59-61.
}

diperoleh oleh orang Kristen setia berdasarkan persyaratan-persyaratan yang ditentukan oleh Gereja Roma Katolik, yang sebagai pelayan penebusan membagikan dan menerapkan dengan otoritas perbendaharaan dan pemuasan Kristus dan orang-orang kudus. Indulgensia tersebut bersifat sebagian atau keseluruhan dengan melihat apakah itu mengangkat sebagian atau seluruh hukuman sementara yang disebabkan oleh dosa. Lebih dari pada itu, indulgensia dapat diterapkan bagi orang yang hidup maupun orang yang telah mati. ${ }^{19}$ Menurut pengajaran keselamatan gereja Roma Katolik, dosa memiliki konsekuensi ganda, yakni hukuman kekal dan hukuman sementara. Pengampunan dosa melibatkan penghapusan hukuman kekal, namun hukuman sementara tetap ada. Setiap dosa, setiap kesalahan kecil, mengakibatkan sebuah noda tidak sehat pada makhluk ciptaan yang harus dimurnikan baik di bumi, maupun setelah kematian di sebuah tempat yang disebut "api penyucian" (purtagori). Perbuatan baik atau kemurahan hati manusia merelasikan orang yang setia di surga dengan orang-orang yang membersihkan dosa mereka pada api penyucian. Menurut pengajaran Roma Katolik, kebaikan-kebaikan rohani dari persekutuan orang-orang suci tersebut adalah perbendaharaan jasa gereja yang memiliki nilai tak terbatas yang berdasarkan jasa-jasa penebusan Yesus Kristus. Namun nilai tak terbatas dari jasa Kristus tersebut dilampaui oleh jasa Maria sebagai bunda Allah dan jasa orang-orang kudus (Santo dan Santa).

Adapun perbendaharaan jasa gereja menurut ajaran keselamatan Roma Katolik tersebut meliputi doa-doa dan perbuatan-perbuatan baik dari Perawan Maria yang diberkati. Doa-doa dan perbuatanperbuatan baik tersebut sungguh-sungguh melimpah dan tidak terukur bahkan bernilai murni di hadapan Allah. Dalam perbendaharaan tersebut mencakup pula doa-doa dan perbuatan-perbuatan baik orangorang kudus, semua orang yang telah mengiringi jejak kaki Tuhan Yesus Kristus yang oleh karena anu-

\footnotetext{
${ }^{19}$ Sproul, Hanya Melalui Iman, 195-196.
} 
gerah-Nya telah mengubah hidup mereka menjadi kudus sehingga dapat melaksanakan misi yang telah Bapa percayakan kepada mereka. Melalui cara demikian maka mereka dapat mencapai keselamatan mereka sendiri dan pada waktu yang sama bekerja sama untuk menyelamatkan orang-orang lain sebagai saudara-saudara mereka dalam persekutuan tubuh rohani. Dengan demikian doktrin penebusan bagi gereja Roma Katolik berdasarkan jasa Kristus, jasa Maria, jasa orang-orang kudus serta perbuatan baik manusia yang bersifat penebusan plus yang transaksional.

Teologi Reformasi melawan semua ajaran Katolik yang menambahkan ha-hal yang cukup sudah dilakukan oleh Kristus untuk penebusan manusia. Para reformator mengajarkan bahwa jasa karya penebusan Kristus sepenuhnya cukup dalam pengertian bahwa penebusan Kristus menghapus dosa orang percaya secara total, memuaskan tuntutan keadilan Allah yang bersifat menghukum manusia berdosa. Nilai pengorbanan Kristus telah memuaskan semua penghakiman Allah terkait dengan realitas manusia yang berdosa dan penuh cacat cela di hadapan-Nya. Adapun ketaatan Yesus Kristus yang sempurna ini menggenapi semua kebenaran, menghasilkan semua jasa yang diperlukan untuk menyelamatkan manusia berdosa yang percaya pada Kristus. Tidak ada yang bisa ditambahkan kepada penebusan Yesus Kristus atau pada kebenaran-Nya untuk menambah nilai dan jasanya ${ }^{20}$.

Pada umumnya berkaitan dengan ajaran penebusan, para reformator mengikuti pemahaman ortodoksi yang mengaitkan antara penebusan dengan substitusi (penggantian) dan pemuasan. Pada waktu Tuhan Yesus menanggung murka Allah, Ia memuaskan tuntutan keadilan Allah yang kudus. Dia menerima murka Allah yang seharusnya diterima oleh manusia yang telah berdosa, dengan demikian manusia berdosa yang mempercayai Tuhan Yesus Kristus dapat terluput dari murka Allah yang akan datang. Tuhan Yesus Kristus tidak mati untuk diri-Nya sen-

\footnotetext{
${ }^{20}$ Ibid, 197.
}

diri namun untuk kita. Penderitaan-Nya di kayu salib adalah mewakili dan menggantikan kita. Dia adalah pengganti kita, orang-orang berdosa. Dia mengambil tempat kita dengan menggenapi peran-Nya sebagai Anak Domba Allah yang menghapus dosa dunia. Dengan demikian tidak memerlukan jasa manusia, sekalipun Maria atau para Santo/Santa sebagaimana yang diajarkan dalam teologi keselamatan versi gereja Roma Katolik.

\section{Kelahiran Kembali (Regenerasi)}

Berkaitan dengan dokrin kelahiran kembali dalam Teologi Roma Katolik terdapat kekacauan pemahaman dengan doktrin pembenaran. Konsep tersebut bersumber dari ajaran Pelagius mengenai kelahiran kembali yang mengajarkan bukan sebagai lahirnya ciptaan baru, melainkan sebagai pengampunan dosa dalam baptisan, iluminasi/pencerahan pikiran oleh kebenaran dan stimulasi/dorongan dari kehendak oleh janji-janji Allah. Gereja Roma Katolik mengajarkan kelahiran kembali terjadi pada saat baptisan. Menurut pengajaran ini, efek dari baptisan adalah penghapusan dosa asal dan aktual dan hukuman yang disebabkan olehnya dan kelahiran kembali di dalam Kristus atau diadopsi sebagai anak. ${ }^{21}$

Pengaruh Skolastik mempengaruhi gereja Roma Katolik sehingga menganggap bahwa kelahiran kembali merupakan tindakan kerja sama antara Allah dan manusia. Dengan kata lain konsep kelahiran kembali dalam teologi gereja Roma Katolik bersifat sinergisme antara Allah dengan manusia yang hakikatnya adalah sama dengan pertobatan atau pengampunan dosa.

Akan tetapi dalam teologi Reformed, kelahiran kembali bukanlah sinergi antara Allah dengan manusia melainkan tindakan Allah yang mana orang berdosa dicurahkan kehidupan rohani yang baru, yang olehnya prinsip-prinsip hidup yang baru tersebut dinyatakan dalam tindakan. Kelahiran kembali

\footnotetext{
${ }^{21}$ Anthony A. Hoekema, Diselamatkan Oleh Anugerah (Surabaya: Momentum, 2013), 141.
} 
merupakan pekerjaan Roh Kudus atas manusia yang secara rohani telah mati karena realitas dosa. Roh Kudus menciptakan kembali hati manusia, membangkitkannya dari kematian secara rohani dan memberikan kehidupan secara rohani. Manusia yang mengalami kelahiran kembali adalah ciptaan yang baru. Pada awalnya manusia tersebut tidak memiliki posisi, kecenderungan maupun kerinduan untuk halhal yang berasal dari Allah, namun setelah kelahiran kembali tersebut sekarang manusia itu berpaling dan memiliki kecenderungan dan kerinduan kepada Allah. Di dalam kelahiran kembali tersebut hidup baru itu dimanifestasikan. Kelahiran kembali adalah penanaman kehidupan yang baru di dalam jiwa, terlepas dari manifestasi pertama dari kehidupan ini. ${ }^{22}$ Dengan demikian kelahiran kembali bukanlah hasil kerja sama antara Allah dengan manusia, melainkan karya Allah semata yang kemudian menghasilkan pertobatan dan membawa kepada kehidupan yang taat dan kudus.

Dalam teologi Reformed juga menegaskan bahwa kelahiran kembali bukanlah merupakan buah atau akibat dari iman, melainkan kelahiran kembali mendahului iman. Kelahiran kembali merupakan kondisi yang dibutuhkan oleh seseorang untuk beriman. Manusia juga tidak berpaling kepada kelahiran kembali atau bekerja sama sebagai rekan kerja dari Roh Kudus untuk menghasilkan kelahiran kembali. Manusia tidaklah memutuskan dan memilih untuk dilahirkan kembali. Allah saja yang memutuskan untuk melahirkan kembali manusia sebelum seseorang akan pernah memilih untuk menerima Dia. Adapun setelah manusia mengalami kelahiran kembali sebagai karya tunggal dari Allah dalam kedaulatan dan anugerah-Nya, maka manusia baru bisa memilih, bertindak, bekerja sama dan percaya kepada Tuhan Yesus Kristus. Allah tidak beriman untuk manusia. Manusia dibenarkan berdasarkan iman manusia itu sendiri. Apa yang dilakukan oleh Allah melalui kelahiran kembali adalah membangkitkan manusia dari keberadaannya yang mati secara rohani, Allah memberi kehidupan secara rohani, membebaskan dari kegelapan, keterikatan dan kematian secara rohani. Melalui kelahiran kembali, Allah memungkinkan/ mengkondisikan manusia untuk percaya kepada$\mathrm{Nya}^{23}$

\section{Pertobatan}

Pengajaran teologi Roma Katolik mengenai pertobatan terkait erat dengan rumusan atau konsep mereka mengenai adanya sakramen pengakuan dosa, yakni pengakuan dosa secara keseluruhan. Unsurunsur yang sangat penting dalam sakramen pengakuan dosa menurut gereja Roma Katolik adalah penyesalan (contrition), pengakuan (confession), pelunasan (satisfaction) dan pengampunan dosa (absolution). Dari keempat unsur tersebut hanya penyesalan (contrition) yang memiliki kaitan langsung dengan pengakuan dosa dan malah dari keempat unsur ini, gereja Roma Katolik menyingkirkan semua penderitaan karena dosa asal, dan hanya menekankan pada pelanggaran-pelanggaran yang dilakukan dengan sengaja oleh manusia/dosa aktual. Oleh karena hanya sedikit saja orang yang mengalami penyesalan (contrition) yang nyata, maka seseorang hanya akan puas dengan pengurangan dosa (attrition). Hal ini merupakan pengakuan mental bahwa dosa harus dihukum, namun tidak mencakup kepercayaan kepada Tuhan serta tidak bertujuan untuk menghindarkan diri dari perbuatan dosa melainkan hanya merupakan suatu bentuk ketakutan terhadap neraka sebagai hukuman. Karena itu, pengakuan dosa dalam gereja Roma Katolik merupakan pengakuan kepada pastur yang bertindak bukan secara deklaratif/pernyataan melainkan yudikatif/pembuat hukum. Implikasi praktis dari model pengakuan dosa yang menjadi sakramen penting dalam gereja Roma Katolik adalah kepuasan akan muncul pada diri manusia berdosa yang menyesal dan mengaku dosa terhadap pastur tersebut, yaitu setelah orang tersebut mengalami se-

\footnotetext{
${ }^{22}$ Berkhof, Teologi Sistematika, 122.
}

\footnotetext{
${ }^{23}$ Sproul, Kebenaran-Kebenaran, 228-229.
} 
suatu yang menyakitkan atau melakukan satu pekerjaan yang sulit dan tidak disukai orang (asketisme). Adapun pusat dari jalan pikiran demikian adalah bahwa perbuatan yang ditunjukkan kepada banyak orang tersebut akan menghasilkan suatu pemuasan atas akibat-akibat dari dosa. ${ }^{24}$

Sebagaimana yang telah diungkapkan di atas dalam teologi reformasi (khususnya Reformed), pertobatan (konversi) merupakan hasil atau akibat dari peristiwa kelahiran kembali (regenerasi). Karena itu dalam pemahaman gerakan reformasi, pertobatan adalah tindakan Allah yang mana Ia menyebabkan orang berdosa yang telah mengalami kelahiran kembali, dalam hidupnya yang disadari, berbalik kepadaNya dalam penyesalan akan dosa dan iman. Pertobatan adalah tindakan yang disadari yang merupakan hasil perbuatan orang berdosa yang mana ia, melalui anugerah Tuhan, berbalik kepada Tuhan dalam kelahiran kembali dan iman. ${ }^{25}$

Secara umum, pertobatan dalam konsep Roma Katolik adalah pengakuan dosa melalui perantara yakni rohaniwan (pastur) dan terkesan sekedar perilaku psikologis manusia yang karena ketakutan akan adanya hukuman maupun realitas pergumulan kehidupan. Sedangkan teologi reformasi justru menegaskan pertobatan sebagai suatu tindakan sukacita sebagaimana yang dinyatakan dalam Katekismus Heildelberg bahwa pertobatan adalah sukacita sepenuh hati di dalam Allah melalui Kristus dan kesenangan untuk melakukan seluruh perbuatan yang benar sebagaimana yang Ia ingin kita lakukan. ${ }^{26}$

Dalam teologi reformasi juga menegaskan bahwa pertobatan bukan merupakan sebab dari kelahiran kembali melainkan pertobatan adalah hasil atau buah dari kelahiran kembali. Pertobatan yang sejati dimulai dari kelahiran kembali serta merupakan sikap dan tindakan yang harus diulangi pada sepanjang kehidupan setiap orang Kristen. Pada saat orang Kristen masih melakukan dosa, maka ia dipe-

\footnotetext{
${ }^{24}$ Berkhof, Teologi Sistematika, 164-165.

${ }^{25}$ Ibid, 157-158.

${ }^{26}$ Hoekema, Diselamatkan, 169.
}

rintahkan untuk bertobat pada saat Roh Kudus menyadarkan akan dosanya. Pertobatan yang dilakukan hanya sekedar karena ketakutan akan penghukuman maupun kehilangan upah adalah pertobatan yang palsu. Pertobatan yang terjadi karena kesadaran akan dosa yang merupakan pemberontakan terhadap Allah sehingga menimbulkan penyesalan adalah pertobatan yang sejati.

\section{Iman}

Sejak gereja mula-mula, konsep iman telah terdapat dalam pemikiran para pemimpin Kristen sebagai satu-satunya syarat utama untuk manusia memperoleh keselamatan. Serangkaian dengan itu, pengakuan dosa juga menjadi sesuatu yang penting. Sekalipun terdapat refleksi berkaitan dengan sifat iman, namun pada saat itu sedikit sekali pemahaman mengenai hubungan antara iman dan bagian-bagian lain dari konsep urutan-urutan dalam keselamatan (ordo salutis). Sebelum reformasi, belum terdapat definisi yang menjelaskan mengenai iman. Memang terdapat satu kecenderungan untuk menggunakan istilah iman yang menunjukkan mengenai realitas penerimaan kebenaran bersumber dari kesaksian. Pemahaman lain mengenai iman mencakup juga penundukan diri sendiri terhadap kebenaran yang diterima secara intelektual. Aliran Kristen Alexandria yang dipengaruhi oleh dualisme filsafat Plato mengkontraskan antara iman (pistis) dan pengetahuan (gnosis), serta meyakini bahwa pistis merupakan pengetahuan yang tidak sempurna pada permulaannya. Tertullianus mengajarkan realitas bahwa iman menerima sesuatu berdasarkan otoritas dan bukan karena dinyatakan oleh pikiran manusia. Demikian pula Tertullianus yang memakai istilah iman dalam pemahaman yang obyektif sebagai sesuatu yang menunjukkan apa yang harus dipercayai (regula fidei). Sampai pada zaman Bapa Gereja terakhir Augustinus, masih terdapat sedikit perhatian yang ditunjukkan pada sifat dari iman, sekalipun iman memang selalui diakui sebagai sarana permulaan yang sangat penting bagi manusia untuk mempero- 
leh keselamatan. Augustinus membicarakan banyak hal terkait dengan iman, bahkan ia mengajarkan mengenai iman yang lebih dari satu pengertian. Augustinus sering memahami iman sebagai pengetahuan intelektual kepada kebenaran. Namun pada sisi yang lain menurut Augustinus, iman kepada Injil atau iman yang membenarkan mencakup juga unsur penundukan diri sendiri serta kasih. Menurutnya, iman nyata disempurnakan dalam kasih yang kemudian menjadi prinsip bagi manusia yang beriman untuk berbuat baik. Sekalipun demikian, Augustinus belum pernah merumuskan dengan tepat dan sistematis kaitan antara iman dengan pembenaran. Oleh karena Augustinus dalam pengajarannya tidak membedakan secara teliti antara pembenaran (justification) dengan pengudusan (sanctification). Konsep inilah yang mempengaruhi pemahaman gereja Roma Katolik mengenai iman.

Pengaruh lain adalah pengaruh dari kaum Skolastik yang merupakan nama yang diberikan untuk teologi dan filsafat yang diajarkan pada gereja abad pertengahan di sekolah-sekolah di Eropa dari abad ke 11 sampai dengan abad ke 14. Kaum Skolastik selalu memahami iman merupakan suatu tindakan pikiran (intelektual). Sekalipun keberadaan iman disebabkan oleh kehendak, namun iman berada di dalam pikiran. Iman merupakan persetujuan atas segala perkara yang telah Allah kemukakan untuk dipercayai. Adapun obyek iman lebih kepada kebenaran-kebenaran tertentu seperti filsafat tertentu maupun tradisi gereja melampaui Pribadi Kristus yang harus dipahami secara intelektual. Dengan konsep iman seperti itu, maka iman tidak lain adalah sebagai persetujuan kepada kebenaran Allah sehingga umat manusia akan bekerja sama dengan anugerah Allah. Jikalau manusia melakukan perbuatan baik, maka akan melayakkan mereka untuk menerima pahala dan dengan demikian akan mempersiapkan diri mereka untuk dibenarkan ${ }^{27}$.

\footnotetext{
${ }^{27}$ Hoekema, Diselamatkan, 183.
}

Kaum Skolastik membuat perbedaan antara iman sebagai suatu pengetahuan intelektual semata kepada kebenaran yang diajarkan oleh gereja (fides informis) dengan iman yang dinyatakan oleh kasih (fides formata/charitate). Fides informis bukan iman yang mendapatkan pengetahuan (informed faith), namun merupakan iman yang belum terbentuk (unformed faith) yang belum memadai atau tidak mencukupi untuk manusia memperoleh pembenaran. Iman yang demikian, menurut kaum skolastik tidak mencakup hubungan pribadi dengan Allah atau dengan Yesus Kristus sebab iman ini hanyalah sebagai persetujuan intelektual terhadap kebenaran yang dinyatakan serta bahkan masih tertahan di dalam dosa-dosa yang mendatangkan maut. Bagi kaum Skolastik, fides formata sebagai satu-satunya iman yang membenarkan sebab mencakup adanya infusi anugerah. Hanya sebagai fides formata sajalah maka iman menjadi aktif untuk kebaikan dan menjadi yang pertama dari kebaikan-kebaikan secara teologis yang olehnya manusia ditempatkan dalam relasi yang sebenarnya dengan Allah. Fides formata adalah iman yang dibentuk oleh kasih. Apabila seseorang menerima kasih ini dan dengan demikian juga akan menerima iman yang sudah terbentuk tersebut melalui baptisan. Jadi sebenarnya yang membenarkan adalah sakramen dan bukan iman. ${ }^{28}$ Dengan demikian kaum Skolastik akan menegaskan bahwa kasih (charity) adalah yang membenarkan manusia serta melalui kasih tersebut maka iman menjadi sempurna. Dengan demikian dalam iman manusia itu sendiri terdapat satu dasar yang diletakkan yakni jasa manusia (teori kontribusi). Menurut gereja Roma Katolik, manusia dibenarkan bukan secara khusus oleh pemberian jasa Kristus melainkan juga oleh anugerah yang terdapat di dalam diri manusia ${ }^{29}$.

Dalam perkembangan pemahaman konsep iman yang demikian, maka dalam gereja Roma Katolik tidak memberi tempat kepada iman sebagai

\footnotetext{
${ }^{28}$ Ibid, 184.

${ }^{29}$ Berkhof, Teologi Sistematika, 186-187.
} 
jaminan kepastian keselamatan serta keyakinan bagi setiap orang percaya akan jaminan tersebut. Karena menurut mereka setiap orang percaya yang awam (bukan rohaniwan) tidaklah mungkin memahami semua pengetahuan kebenaran yang diajarkan oleh gereja, maka dia tidak perlu mempercayai semua kebenaran tersebut dengan iman yang eksplisit, namun dia dapat menerima sedikit, jika bukan sebagian besar dari kebenaran tersebut dengan suatu "iman yang implisit" (fides implicita) yakni cukup dengan menyetujui hal-hal yang diajarkan oleh gereja. Iman bukanlah penghubung kepada Pribadi Kristus dan karya keselamatan-Nya melainkan persetujuan akan ajaran-ajaran gereja. Oleh sebab itu, maka orang percaya tidak pernah dapat memperoleh keyakinan mutlak mengenai keselamatan pribadi mereka melainkan hanya terbatas kepada semacam keyakinan dugaan yang tetap terdapat kemungkinan untuk seseorang mengalami kehilangan keselamatannya. ${ }^{30}$

Apabila teologi gereja Roma Katolik mengikuti pandangan kaum Skolastik bahwa di dalam iman sendiri terdapat beberapa kebaikan yang nyata dan bahkan jasa dalam memperoleh pembenaran, maka para reformator mengajarkan bahwa iman yang membenarkan tidaklah membenarkan berdasarkan jasa kebaikan manusia itu sendiri, tetapi hanya sebagai sarana atau alat untuk menerima atau bersandar pada apa yang telah disediakan oleh Tuhan dalam jasa-jasa pekerjaan Yesus Kristus. Iman adalah pemberian Tuhan dan tindakan manusia hanya merupakan hal yang kedua dalam ketergantungan kepada Tuhan.

Johanes Calvin dan teologi reformed menolak pandangan kaum Skolastik mengenai iman hanya sebagai suatu persetujuan intelektual serta menolak konsep iman yang implisit sebagai sikap penundukan diri secara mutlak kepada pengajaran gereja tanpa benar-benar mengerti ajaran tersebut apakah Alkitabiah ataukah tidak. Menurut Calvin, iman semacam ini hanyalah ketidaktahuan dan bukannya

\footnotetext{
${ }^{30}$ Hoekema, Diselamatkan, 184.
}

pengetahuan yang hanya akan menguburkan kebenaran bahkan menghancurkan kebenaran tersebut secara total. Calvin juga menolak pembedaan gereja Roma Katolik antara fides informis dan fides formata. Bagi Calvin, fides informis bukanlah iman yang sejati sebab dengan iman seperti ini maka seseorang yang tidak takut akan Allah dan tidak memiliki kesalehan dinyatakan mampu untuk mempercayai hal yang diperlukan untuk memperoleh keselamatan. Menurut Calvin fides informis tidak lain hanya sebagai bayangan atau kiasan dari iman namun bukanlah iman yang nyata/valid. Menurut Calvin iman yang sejati terdiri dari pengetahuan akan Allah, khususnya mengenai kasih setia Tuhan. Johanes Calvin menegaskan bahwa iman merupakan pengetahuan yang teguh dan pasti dari suatu janji yang bebas dalam Kristus serta diungkapkan dalam pikiran kita, dan dimeteraikan di dalam hati kita oleh Roh Kudus. ${ }^{31}$ Sebenarnya pada saat Calvin merujuk kepada unsur hati yang berbeda dari pikiran, maka yang dimaksudkannya dengan hati adalah kehendak dan emosi/perasaan ${ }^{32}$.

Bagi Calvin iman tidaklah semata sebagai pengetahuan intelektual, namun seperti Luther, Calvin mengajarkan bahwa kepercayaan adalah hakikat dari iman. Iman adalah keyakinan yang teguh dan efektif. Selanjutnya Calvin menegaskan bahwa pengetahuan akan Kristus (sebagai obyek iman) merupakan suatu pengajaran, namun bukan sekedar perkataan atau teoritis semata, melainkan sebagai suatu pengajaran dari kehidupan. Pengetahuan yang demikian bukan dipahami seperti disiplin-disiplin yang hanya terdiri dari pemahaman dan ingatan melulu, melainkan pengetahuan akan Kristus baru benar-benar akan dapat diterima apabila ia telah memiliki keseluruhan jiwa dan mendapatkan tempat bertakhta dan berdiam di dalam kasih yang paling dalam di hati manusia.

\footnotetext{
${ }^{31}$ Berkhof, Teologi Sistematika, 188.

${ }^{32}$ Hoekema, Diselamatkan, 185.
} 
Pengajaran Calvin sungguh bertolak belakang dengan pendapat kaum Skolastik yang pada umumnya dipegang oleh gereja Roma Katolik. Bagi Calvin dan kaum reformator gereja, iman merupakan suatu hubungan pribadi dengan Allah dan dengan Kristus, pengetahuan yang pasti akan kasih Allah dan anugerah-Nya di dalam Kristus, bukan hanya sekedar suatu persetujuan terhadap kebenaran-kebenaran yang mungkin hanya setengah dipahami atau bahkan tidak dipahami sama sekali. Iman adalah suatu keyakinan yang teguh atau kepercayaan yang teguh berlawanan dengan sikap ragu-ragu. Pada akhirnya Calvin dan gerakan reformasi menolak semua pengajaran gereja Roma Katolik yang menempatkan iman sebagai pahala bagi perbuatan baik manusia $^{33}$.

Bagi para reformator, orang dibenarkan/diselamatkan hanya melalui iman. Karena begitu pentingnya iman, maka mereka menjelaskan elemenelemen apa saja yang tercakup dalam iman yang menyelamatkan tersebut yang terdiri dari informasi, pengertian secara intelektual dan kepercayaan secara pribadi. Isi tercakup di dalam iman yang menyelamatkan karena manusia tidak dibenarkan atau diselamatkan hanya karena beriman pada apa saja. Alkitab menegaskan bahwa apa yang manusia percayai memiliki pengaruh yang sangat mendalam. Pengajaran atau doktrin yang benar yakni kebenaran-kebenaran dasar dari Injil merupakan suatu keharusan dalam iman yang menyelamatkan. Manusia harus percaya pada Injil yang menyaksikan akan pribadi dan karya Tuhan Yesus Kristus. Informasi yang benar mengenai pribadi dan karya Kristus juga mengharuskan adanya pikiran yang mengakui kebenaran dari hal itu. Seseorang harus mengakui bahwa apa yang Alkitab ajarkan mengenai kebenaran pribadi dan karya Yesus Kristus untuk menyelamatkan manusia melalui kematian dan kebangkitan-Nya serta realitas bahwa hanya di dalam Yesus Kristus satu-satunya jalan keselamatan bagi manusia berdosa adalah un-

\footnotetext{
${ }^{33}$ Hoekema, Diselamatkan, 185.
}

sur penting bagi iman yang menyelamatkan. Pemahaman dan pengakuan akan kebenaran-kebenaran Injil adalah unsur penting dalam iman, namun masih ada satu unsur lagi yakni percaya untuk memperoleh iman yang menyelamatkan yang melibatkan penyerahan diri seseorang dan kebergantungan dirinya pada Tuhan Yesus Kristus sebagai Tuhan dan Juruselamat. Kepercayaan secara pribadi mutlak perlu bagi seseorang untuk memperoleh keselamatan dan merupakan hal yang ada setelah pengertian secara intelektual. Hal ini yang diungkapkan oleh Luther bahwa iman adalah kepercayaan yang vital dan pribadi kepada Kristus sebagai Juruselamat dan Tuhan. ${ }^{34}$

Doktrin mengenai iman adalah doktrin yang juga sangat sentral dalam gerakan reformasi gereja. Hanya melalui iman (sola fide) adalah salah satu moto gerakan reformasi gereja. Bagi Martin Luther, sola fide adalah ajaran yang menjadi landasan utama dan alasan berdirinya gereja, yang tanpanya gereja akan ambruk. ${ }^{35}$

\section{Pembenaran}

Sampai pada abad pertengahan, tidak terdapat kejelasan doktrin mengenai pembenaran pada kalangan gereja Roma Katolik. Dalam pengajaran teologi Skolastik, pembenaran menyangkut dua unsur yaitu dosa manusia diampuni dan ia dijadikan adil atau benar. Teolog Roma Katolik terkemuka pada abad pertengahan, Thomas Aquinas mengajarkan bahwa anugerah diberikan kepada manusia dimana kemudian ia dijadikan benar dan sebagian lagi oleh karena anugerah yang diberikan inilah maka dosa manusia itu diampuni. Pendapat demikian lalu menjadi pendekatan bagi suatu doktrin mengenai jasa yang jahat, yang makin lama makin perkembangan pada gereja abad pertengahan dalam hubungan dengan pengajaran mengenai pembenaran. Konsep ini mengajarkan juga bahwa manusia diselamatkan sebagian karena perbuatan baik yang dilakukannya.

\footnotetext{
${ }^{34}$ Sproul, Kebenaran-Kebenaran, 249.

${ }^{35}$ Sproul, Hanya Melalui Iman, 90.
} 
Terjadi kekacauan pemahaman antara doktrin pembenaran dengan pengudusan sehingga membuat pengajaran keselamatan menjadi begitu menyimpang. Sebagian dari kaum Skolastik membicarakan bahwa pembenaran sebagai satu tindakan seketika dari Tuhan, sedangkan kelompok Skolastik lain memahami pembenaran sebagai tindakan yang terjadi dalam proses.

Pada umumnya doktrin pembenaran dalam teologi keselamatan dari Gereja Roma Katolik merupakan pencampuran antara warisan pengajaran Pelagius dengan teologi akademik abad pertengahan yakni Skolastik. Menurut mereka, manusia diselamatkan karena Allah telah berjanji bahwa Ia menganggap seseorang layak untuk diselamatkan apabila ia berbuat baik sesuai dengan kemampuannya. Mereka tidaklah menyangkal bahwa semua manusia itu lemah dan berdosa, namun apabila ia sungguh-sungguh berupaya, maka Allah akan menyelamatkannya. Karena itu, Allah akan menambahkan pada perbuatan-perbuatan baik yang dilakukan oleh manusia dan yang tidak cukup untuk diupahi dengan kehidupan kekal, apa yang masih dibutuhkan oleh manusia untuk memperoleh pembenaran atau keselamatan. $^{36}$

Kepercayaan gereja Roma Katolik berkaitan dengan doktrin pembenaran juga merujuk kepada hasil keputusan Konsile Trente yang diselenggarakan pada tanggal 21 Juni 1546 sampai dengan 13 Januari 1547 yang sebenarnya merupakan konsili kontra reformasi. Mereka menentang doktrin pembenaran melalui iman yang ditegaskan oleh Marthin Luther serta para reformator. Dalam konsili Trente dinyatakan bahwa apabila seseorang berkata dengan iman saja orang dibenarkan, maka artinya tidak ada syarat lain untuk bekerja sama untuk memperoleh anugerah pembenaran dan memang sama sekali tidak dibutuhkan jika ia harus bertindak berdasarkan kehendak diri sendiri dan bukan keputusan gereja.

${ }^{36}$ Christiaan De Jonge, Gereja Mencari Jawab; Kapita Selekta Sejarah Gereja (Jakarta: PT BPK Gunung Mulia, 2000), 25.
Bagi kaum Roma Katolik, pembenaran adalah suatu proses sebab menurut mereka apabila seseorang berkata bahwa keadilan yang diterimanya tidak disediakan dan ditingkatkan di hadapan Allah melalui pekerjaan baik, serta mengajarkan bahwa pekerjaan itu hanya sekedar buah dan tanda dari pembenaran yang diperolehnya bukan penyebab dan peningkatan yang dimaksud maka hal itu berlawanan dengan keputusan gereja Roma Katolik ${ }^{37}$.

Menurut gereja Katolik, pembenaran pada dasarnya dianggap sebagai penanaman (infusi) anugerah yang mengakibatkan suatu perubahan di dalam natur rohani dan moral manusia, dan bukan merupakan suatu tindakan deklaratif, di mana Allah mengimputasikan kebenaran Kristus kepada orang yang percaya. Dalam hal ini apabila ada seseorang yang berkata bahwa manusia dibenarkan melalui pengimputasian kebenaran Kristus saja atau melalui penghapusan dosa saja, dengan tidak memasukkan anugerah dan kasih yang dicurahkan di dalam hati mereka oleh Roh Kudus dan tetap berada di sana atau bahwa anugerah yang membenarkan kita hanyalah kehendak baik dari Allah, maka orang yang demikian dibiarkan menjadi terkutuk. Dengan demikian pembenaran tidak dilihat sebagai hal yang forensik atau deklaratif, melainkan sebagai suatu penanaman anugerah yang menghasilkan pengudusan yang mana manusia mengambil partisipasi dengan perbuatan baiknya.

Bagi gereja Roma Katolik berkaitan dengan hubungan antara pembenaran dengan iman, maka iman tidak memiliki signifikansi inti di dalam pembenaran, melainkan menempati tempat yang lebih rendah. Iman hanyalah sebagai bagian dari tahap persiapan untuk pembenaran, sedangkan iman yang mereka maksudkan adalah "iman yang belum terbentuk" (fides informis) yang mereka sebutkan sebagai sesuatu yang belum memadai untuk pembenaran. Karena itu dilanjutkan dengan "iman yang terbentuk oleh kasih" (fides formata) yang akan ter-

\footnotetext{
${ }^{37}$ Berkhof, Teologi Sistematika, 222.
} 
jadi apabila seseorang menerima anugerah yang ditanamkan melalui baptisan. Karena itu bagi kebanyakan penganut Roma Katolik, hal yang benarbenar membenarkan manusia bukanlah iman, melainkan sakramen baptisan ${ }^{38}$.

Pembenaran versi gereja Roma Katolik juga meyakini bahwa setelah seseorang menerima anugerah pembenaran tersebut masih terdapat kemungkinan untuk hilang karena adanya ketidakpercayaan dan dosa maut. Kebenaran yang diterima seseorang juga dapat ditingkatkan melalui ketaatan dalam melakukan perintah-perintah Allah dan gereja, iman yang bekerja sama dengan perbuatan baik. Dengan demikian bagi mereka, pembenaran bukan sebagai imputasi kebenaran sempurna dari Yesus Kristus terhadap manusia berdosa yang percaya kepada-Nya, melainkan sebagai kualitas subyektif di dalam diri manusia yang memiliki kemungkinan untuk bertambah maupun berkurang. Pada akhirnya gereja Roma Katolik mempercayai bahwa pembenaran memampukan orang percaya untuk memperoleh pahala untuk menjadikan dia berhak memperoleh kehidupan yang kekal melalui perbuatan baik. Memang perbuatan-perbuatan baik yang dilakukan oleh orang yang telah dibenarkan pada satu sisi merupakan anugerah Allah dan jasa Yesus Kristus, namun perbuatan-perbuatan baik juga merupakan jasa dari orang yang dibenarkan itu sendiri. Dengan melakukan perbuatan-perbuatan baik, maka orang yang telah dibenarkan tersebut akan memiliki hak memperoleh anugerah yang semakin bertambah, kehidupan kekal dan bahkan bertambahnya kemuliaan. ${ }^{39}$

Adapun doktrin pembenaran merupakan prinsip besar dari gerakan reformasi gereja. Dengan meneliti, memahami dan meyakini sifat dari pembenaran menurut Alkitab maka para reformator memperbaiki kesalahan dan penyimpangan ajaran gereja Roma Katolik yang mencampuradukkan antara pembenaran dengan pengudusan. Tentang pembenaran,
Martin Luther menegaskan bahwa ajaran mengenai pembenaran adalah tuan dan raja, penguasa dan hakim atas segala macam doktrin yang lain; ajaran tersebut menjaga dan mengendalikan semua doktrin gereja serta membangkitkan hati nurani kita di hadapan Allah. Karena itu, tanpa ajaran ini dunia akan mati sama sekali serta diliputi oleh kegelapan. Selanjutnya, Luther juga menegaskan apabila bagian ajaran mengenai pembenaran ini hilang, maka semua doktrin Kristen akan hilang pada saat yang bersamaan. ${ }^{40}$ Menurut Luther, apabila gereja memelihara doktrin pembenaran dengan benar, maka gereja secara mendasar akan benar di dalam semua ajarannya yang lain, tetapi jika gereja tidak setia terhadap doktrin pembenaran ini, maka gereja akan salah pada semua pengajarannya yang lain. ${ }^{41}$

Luther menemukan kembali doktrin pembenaran dalam Alkitab yang telah lama diselewengkan oleh gereja Roma Katolik melalui pengalaman pribadinya, penelitian akan tulisan Augustinus serta memahami secara baru surat Paulus kepada jemaat di Roma (pasal 1:16-17) yakni mengenai istilah "keadilan/kebenaran Allah" (iustitia Dei) yang adalah istilah kunci dalam ajaran mengenai pembenaran manusia (justificatio). Dalam keadilan-Nya, Allah tidak menghakimi manusia secara adil menurut perbuatannya sehingga ia pasti akan binasa, namun membebaskannya dari hukuman akibat dosa karena jasa Yesus Kristus. Seseorang yang mempercayakan diri dengan iman saja (sola fide) kepada Allah yang penuh anugerah, akan dibenarkan, dianggap dan dinyatakan benar karena kebenaran Kristus dihitung oleh Allah sebagai kebenaran orang percaya. Dengan demikian, hal pembenaran manusia berdosa bukan disebabkan oleh usaha manusia namun anugerah Allah saja sebagai sumber keselamatan manusia. $^{42}$

Johanes Calvin juga menegaskan hal yang sama mengenai doktrin pembenaran yaitu sebagai

\footnotetext{
${ }^{40}$ Sproul, Hanya Melalui Iman, 90-91.

${ }^{41}$ Hoekema, Diselamatkan, 202.

${ }^{42}$ De Jonge, Gereja Mencari Jawab, 25-26.
} 
landasan utama yang harus menjadi dasar agama, karena itu perlu mendapatkan perhatian dan kepedulian yang lebih besar. Karena kecuali seseorang terlebih dahulu memahami posisinya di hadapan Allah, dan hukuman apa yang dijatuhkan-Nya kepadanya, maka orang itu tidak memiliki landasan yang menjadi dasar bagi keselamatannya atau dasar untuk mempersembahkan kesalehan di hadirat Allah. Calvin bahkan menegaskan bahwa doktrin pembenaran adalah engsel utama yang padanya agama berputar. ${ }^{43}$

Bagi para reformator terutama Luther dan Calvin menyatakan hal yang begitu penting mengenai doktrin pembenaran sebagai landasan atau dasar dengan menekankan bahwa begitu pentingnya Injil yang menjadi dasar atau landasan dari keselamatan diantaranya penjelasan mengenai bagaimana seseorang ditebus oleh Tuhan Yesus Kristus. ${ }^{44}$ Berdasarkan keyakinan dan pengajaran para reformator mengenai doktrin pembenaran, maka teolog Reformed James I. Packer meringkaskan secara lengkap signifikansi dari doktrin pembenaran tersebut bahwa sebagaimana dipahami oleh para reformator dan pengikut-pengikut mereka, dan oleh Paulus maka tema pembenaran ini bersifat teologis yang menyatakan suatu karya anugerah Allah yang luar biasa. Hal ini juga bermakna antropologis yang menunjukkan bahwa manusia tidak dapat menyelamatkan diri sendiri. Bersifat Kristologis yang bersandarkan pada pribadi Allah yang berinkarnasi yaitu Tuhan Yesus Kristus dan karya pendamaian-Nya. Bersifat pneumatologis yang menekankan kesatuan iman dengan Yesus Kristus yang dikerjakan oleh Roh Kudus. Bersifat ekklesiologis yang menentukan definisi dari gereja dan kesehatan maupun bersifat eskatologis yaitu memproklamasikan keputusan akhir Allah yang sesungguhnya atas diri orang-orang percaya kini dan di sini. Doktrin pembenaran juga memiliki implikasi praktis, yakni evangelistis yakni mengundang jiwa yang berada di dalam kesusahan pada da- mai sejahtera yang kekal. Bersifat pastoral, yakni menjadikan identitas orang percaya yang adalah orang-orang berdosa yang diampuni sebagai dasar dari persekutuan kita serta liturgis yang sangat menentukan dalam menafsirkan sakramen-sakramen dan membentuk pelayanan sakramen. Tidak ada doktrin alkitabiah lain yang begitu kaya yang menyatakan begitu banyak hal yang berharga dan menghidupkan seperti doktrin pembenaran. ${ }^{45}$

Para reformator memberikan penekanan sangat kuat terhadap doktrin pembenaran sebagai tindakan anugerah Allah yang cuma-cuma, dimana Tuhan mengampuni dosa manusia dan menerima manusia sebagai orang benar dalam pandangan-Nya, tetapi tidak mengubah kita dalam batin. Mereka menolak pandangan gereja Roma Katolik mengenai dasar pembenaran adalah kebenaran yang dimiliki dari seseorang yang telah mengalami kelahiran kembali dan dalam perbuatan baik. Bagi para reformator, dasar pembenaran hanya ditemukan dalam kebenaran yang diberikan oleh Tuhan Yesus Kristus sebagai Juruselamat. Para reformator menekankan kenyataan bahwa manusia dibenarkan dengan cuma-cuma karena iman yang menerima dan bersandar kepada Tuhan Yesus Kristus yang menyelamatkan. Para reformator menolak doktrin pembenaran versi Roma Katolik yang mengakui pembenaran bersifat proses atau progresif. Para reformator berpegang bahwa pembenaran itu terjadi seketika dan lengkap serta tidak tergantung pada pembayaran dosa lebih lanjut. ${ }^{46}$

Bagi para reformator, doktrin pembenaran merupakan tindakan anugerah dan huku Allah yang dengannya Allah menyatakan bahwa orang-orang berdosa yang percaya sebagai orang benar berdasarkan kebenaran Tuhan Yesus Kristus yang diperhitungkan kepada mereka, mengampuni semua dosa mereka, mengangkat mereka sebagai anak-anak-Nya serta memberikan kehidupan kekal terhadap mereka. Karena itu bagi para reformator dan teologi Refor-

\footnotetext{
${ }^{43}$ Hoekema, Diselamatkan, 202.

${ }^{44}$ Sproul, Hanya Melalui Iman, 91.
} 
med, konsep pembenaran mempresaposisikan adanya pengakuan atas realitas dari murka Allah karena gelapnya dosa manusia. Pembenaran adalah suatu tindakan deklaratif atau yudisial dari Allah dan bukan merupakan suatu proses serta hal tersebut terjadi satu kali untuk selamanya pada saat seseorang menerima Tuhan Yesus Kristus melalui iman. Pembenaran yang diterima melalui iman oleh seseorang yang menerima Tuhan Yesus Kristus berarti pembenaran tersebut bukanlah pahala bagi perbuatan manusia. Karena itu, pembenaran berakar dalam kesatuan dengan Yesus Kristus sehingga kebenaran Yesus Kristus diperhitungkan dan menjadi milik manusia yang beriman kepada-Nya. Pembenaran juga didasarkan kepada karya penggantian Yesus Kristus bagi kita. Hal ini melibatkan tindakan Kristus yang telah mengambil tempat kita dan menanggung bagi kita murka Allah terhadap dosa-dosa kita yang sebenarnya layak kita terima. Pada saat Yesus Kristus mati di atas kayu salib, Ia menanggung kutuk itu sebagai ganti kita manusia yang berdosa, sebagai pengganti kita, bahkan Ia telah menjadi kutuk demi kita, sehingga kita dapat diselamatkan dari kutuk tersebut. Luther dalam komentarnya mengenai teks Galatia 3: 13 menegaskan bahwa Bapa yang penuh rahmat, melihat manusia begitu tertekan dan ditaklukan oleh kutuk hukum Taurat, dan begitu terikat pada kutuk itu sehingga manusia tidak akan dapat menyelamatkan diri dengan kekuatan sendiri, maka Dia mengutus Yesus Kristus Anak-Nya ke dalam dunia dan menanggungkan kepada-Nya seluruh dosa umat manusia dan berkata kepada-Nya, jadilah engkau Petrus, yang adalah seorang penyangkal; Paulus, seorang penganiaya, penghujat dan penindas yang kejam; Daud, seorang pezinah; mereka yang memakan buah terlarang di Taman Eden; penjahat yang disalibkan; singkatnya, jadilah Engkau pribadi yang telah melakukan semua dosa semua manusia; dan oleh karena itu, bayarlah semua itu dan berikan pemuasan sebagai ganti mereka ${ }^{47}$.

\footnotetext{
${ }^{47}$ Hoekema, Diselamatkan, 231-232.
}

Bagi para reformator, konsep pembenaran juga memiliki banyak sifat lainnya. Pembenaran meliputi pengimputasian kebenaran Kristus kepada mereka yang beriman kepada-Nya. Allah mendeklasikan orang-orang percaya sebagai orang benar karena Allah menganggap mereka sebagai benar. Allah memperhitungkan kebenaran kepada mereka yang percaya pada Tuhan Yesus Kristus bukan karena Allah menganggap mereka telah mentaati hukum Taurat secara pribadi, namun Allah memperhitungkan orang percaya telah disatukan dengan Yesus Kristus yang telah mewakili mereka menaati hukum Taurat-Nya. Di dalam pembenaran, maka anugerah dan keadilan Allah dinyatakan bersama-sama. Pada satu sisi pembenaran merupakan anugerah dan kemurahan Allah yang sangat luar biasa sebab semua manusia tidak layak untuk menerimanya. Pada sisi yang lain, Allah dapat membenarkan manusia yang beriman kepada Yesus Kristus karena keadilan Allah telah dipuaskan secara sempurna oleh karya pendamaian Yesus Kristus, yang mana Anak Tunggal Allah menanggung murka Allah pada kayu salib yang selayaknya diterima oleh semua manusia. Ketaatan Yesus Kristus yang sempurna kepada hukum Taurat mewakili manusia beriman. Seharusnya ketaatan kepada hukum Taurat dijalankan oleh semua manusia, namun karena ketidakberdayaan semua manusia yang menyandang status orang berdosa, maka Yesus Kristus telah menggenapi itu dengan sempurna. Demikian juga pembenaran berarti pengampunan terhadap dosa-dosa kita serta pengangkatan orang-orang berdosa yang telah percaya kepada Tuhan Yesus Kristus sebagai anak-anak Allah dan penerimaan hak untuk memiliki kehidupan kekal berdasarkan anugerah Allah dan jasa Tuhan Yesus Kristus yang membenarkan. Pada akhirnya, doktrin pembenaran memiliki implikasi eskatologis yakni bahwa keputusan yang akan dijatuhkan Allah kepada manusia berdosa di hari penghakiman telah dinyatakan pada saat ini yang mana setiap orang yang percaya kepada Yesus Kristus telah berpindah dari kematian kepada kehidupan (Yoh. 5:24). Peng- 
angkatan setiap orang percaya menjadi anak-anak Allah merupakan salah satu dari hasil pembenaran yang diberikan oleh Allah yang mengarah ke depan kepada penyempurnaan berkat tersebut di masa yang akan datang (Rm. 8:23). Hak untuk memperoleh hidup kekal sebagai anugerah Tuhan melalui pembenaran terhadap mereka yang percaya pada Tuhan Yesus Kristus adalah karunia yang kekal (Yoh. 11:25-26). Karena itu, berbeda dengan pemahaman gereja Roma Katolik mengenai pembenaran sebagai proses dan dapat hilang, maka berdasarkan Alkitab, teologi reformasi menegaskan bahwa pembenaran yang telah diterima tidak akan pernah hilang.

\section{Pengudusan}

Berkaitan dengan konsep pengudusan sebagai salah satu aspek dalam teologi keselamatan, maka gereja Roma Katolik mengikuti kecenderungan pemikiran teologi gereja abad pertengahan terutama pemikiran Thomas Aquinas. Pada hakikatnya, Aquinas tidak membedakan dengan jelas antara pembenaran (justificatio) dengan penyucian (sanctificatio). Pada hakikatnya pembenaran merupakan penanaman (infusi) anugerah Allah ke dalam jiwa manusia yang olehnya jiwa manusia tersebut diangkat menuju satu tingkatan baru yang lebih tinggi atau dalam kedudukan yang lebih tinggi serta jiwa manusia tersebut dimampukan untuk dapat memperoleh tujuan surgawinya untuk dapat mengenal, memiliki, dan menikmati hubungan dengan Allah. Sesungguhnya menurut para teolog abad pertengahan, anugerah diperoleh melalui jasa-jasa Kristus yang tidak pernah habis dan diberikan kepada orang percaya melalui sakramen-sakramen. Apabila dilihat dari sudut pandang Allah, anugerah yang menguduskan dalam jiwa manusia memastikan adanya remisi bagi dosa asal, kemudian menanamkan kebiasaan yang menetap dari kebenaran batiniah, dan membawa potensi untuk berkembang lebih lanjut, bahkan dapat mencapai kesempurnaan. Dari hidup yang baru, kemudian mengeluarkan kebaikan-kebaikan. Ada-pun perbuatan baik manusia dapat dinetralisa- sikan atau bahkan dapat dihancurkan oleh dosa-dosa yang mendatangkan maut, namun kesalahan yang telah dilakukan setelah baptisan dapat disingkirkan melalui sakramen ekaristi. Maksudnya kesalahan tersebut merupakan dosa yang ringan atau dapat diampuni melalui sakramen pengakuan dosa dalam hal dosa-dosa yang mendatangkan maut. Sedangkan apabila dipandang dari sudut manusia, karya supranatural dari iman yang bekerja melalui kasih telah mencapai jasa di hadapan Tuhan dan memastikan akan adanya anugerah yang makin meningkat. Sekalipun demikian pekerjaan seperti itu sangat tidak mungkin tanpa adanya karya anugerah Allah yang terus menerus. Hasil dari keseluruhan proses ini menurut pemahaman gereja Roma Katolik lebih dikenal sebagai pembenaran yakni hal yang menjadikan manusia benar di hadapan Allah dan bukannya pengudusan. ${ }^{48}$

Para reformator gereja sebaliknya membuat perbedaan antara pembenaran dengan pengudusan. Aspek pembenaran menurut para reformator seperti yang telah diungkapkan di atas adalah suatu tindakan menurut hukum dari anugerah Allah yang memungkinkan adanya status hukum bagi manusia berdosa yang dinyatakan benar karena mereka percaya kepada Kristus yang telah membenarkan dan menggantikan mereka melalui karya-Nya di kayu salib. Sedangkan pengudusan adalah karya ciptaan baru (rekreatif) yang bersifat moral, yang mengubah sisi batiniah dari natur manusia. Bagi para reformator, pembenaran segera diikuti oleh pengudusan, sebab Allah mengirimkan Roh Anak-Nya ke dalam hati umat-Nya segera sesudah mereka dibenarkan, dan Roh itu adalah Roh pengudusan. Anugerah pengudusan bukanlah sesuatu yang diterima manusia beriman melalui sakramen melainkan karya Roh Kudus yang olehnya Ia melepaskan orang percaya terus menerus dari kuasa dosa dan memampukannya untuk berbuat baik. Dengan demikian bagi para reformator, pengudusan sebagai kelanjutan dari karya anu-

\footnotetext{
${ }^{48}$ Berkhof, Teologi Sistematika, 259.
} 
gerah Allah yang telah membenarkan manusia beriman melalui Roh Kudus namun melibatkan tanggung jawab dan partisipasi manusia. Dengan pengudusan tersebut, Roh Kudus melepaskan seseorang dari pencemaran dosa, memperbaharui keseluruhan natur manusia menurut gambar Allah serta memampukan seseorang yang telah percaya kepada Tuhan Yesus Kristus untuk menjalankan kehidupan yang berkenan di hadapan Allah sebagai tujuan Allah yang penuh anugerah dalam menyelamatkan anakanak-Nya di dalam Tuhan Yesus Kristus.

\section{KESIMPULAN}

Sejarah gereja mencatat betapa gelapnya keberadaan gereja abad pertengahan, gereja Roma Katolik yang telah menjadi mapan sejak dinyata-kan sebagai agama negara oleh Kaisar Konstantine pada abad ke 5. Zaman kegelapan gereja memang dipengaruhi oleh masuknya kepentingan politik di dalam gereja, serta berkembangnya ajaran-ajaran filsafat dan tradisi yang cenderung melampaui dan menyelewengkan kebenaran Alkitab. Terutama pengajaran mengenai keselamatan sebagai doktrin yang sangat penting dalam Alkitab dan bagi gereja karena menyangkut mengenai kekekalan manusia di hadapan Tuhan. Sekalipun Alkitab dengan jelas telah menegaskan mengenai eksistensi manusia yang berdosa secara sifat dasar maupun aktual, realitas

\section{DAFTAR RUJUKAN}

Aritonang, Jan Sihar. Garis Besar Sejarah Reformasi. Bandung: Jurnal Info Media, 2007.

Becker, Dieter. Pedoman Dogmatika. Jakarta: PT BPK Gunung Mulia, 2012.

Berkhof, Louis. Teologi Sistematika, Jilid 4. Surabaya: Momentum, 2001.

De Jonge, Christiaan. Gereja Mencari Jawab; Kapita Selekta Sejarah Gereja. Jakarta: PT BPK Gunung Mulia, 2000.

Enns, Paul. The Moody Handbook of Theology Jilid 1. Malang: Literatur SAAT, 2014. anugerah Allah yang telah dinyatakan melalui Pribadi dan Karya pendamaian Tuhan Yesus Kristus di kayu salib serta pentingnya iman sebagai sarana menerima keselamatan, namun oleh pengajaran gereja Roma Katolik pada abad pertengahan hal-hal tersebut dikesampingkan dan diganti dengan kemampuan manusia untuk memperoleh keselamatan.

Syukur kepada Tuhan, sebab sejarah juga mencatat adanya gerakan reformasi gereja pada abad ke 15 yang sebenarnya bukan untuk menciptakan denominasi gereja baru, namun bertujuan untuk memperbaiki pengajaran gereja yang telah menyeleweng dengan mengembalikan kepada kemurnian pengajaran Alkitab. Para reformator berhasil mengungkapkan kembali pengajaran-pengajaran dasar iman Kristen dengan memberi penekanan kepada anugerah Allah yang menjadi satu-satunya alasan dan sumber keselamatan manusia yang sudah begitu nyata nampak di dalam Pribadi dan karya pendamaian Tuhan Yesus Kristus.

Pada akhirnya, hanya dapat diperbandingkan dan sekaligus disimpulkan bahwa pengajaran keselamatan menurut gereja Roma Katolik sebelum reformasi berpusatkan pada manusia (antroposentris), sedangkan pengajaran keselamatan yang ditegaskan oleh para reformator berpusatkan hanya kepada Allah (Theosentris).

Ferguson, Sinclair. Anugerah Pertobatan. Bandung: Penerbit Mitra Pustaka, 2007.

Groenen, C. Soteriologi Alkitabiah. Yogyakarta: Penerbit Kanisius, 1989.

Hoekema, Anthony A. Diselamatkan Oleh Anugerah. Surabaya: Momentum, 2013.

Jacob, Tom. Syalom, Salam, Selamat. Yogyakarta: Penerbit Kanisius, 2007.

Lane, Tony. Runtut Pijar: Sejarah Pemikiran Kristiani. Jakarta: BPK Gunung Mulia, 2012.

Lohse, Bernhard. Pengantar Sejarah Dogma Kristen. Jakarta: PT BPK Gunung Mulia, 2011. 
Marantika, Chris. Doktrin Keselamatan dan Kehidupan Rohani. Yogyakarta: Iman Press/Sekolah Tinggi Teologia Injili Indonesia, 2002.

McGrath, Alister E. Sejarah Pemikiran Reformasi. Jakarta: PT BPK Gunung Mulia, 2012.

Ryrie, Charles. Teologi Dasar 2. Yogyakarta: Penerbit Andi, 2006.

Situmorang, Jonar. Soteriologi: Doktrin Keselamatan. Yogyakarta: Penerbit Andi, 2015.
Sproul, R.C. Hanya Melalui Iman. Bandung: Penerbit Mitra Pustaka, 2004.

Sproul, R.C. Kebenaran-Kebenaran Dasar Iman Kristen. Malang: Literatur SAAT, 2005.

Tong, Stephen. Reformasi dan Teologi Reformed. Jakarta: Lembaga Reformed Injili Indonesia, 1999. 